(NASA-TM-111195) NEW GENERATION OF PLASMA-SPRAYED MULLITE COATINGS ON N96-17175 SILICON CARBIDE (NASA. LEWIS Research Center) $6 \mathrm{P}$

Unclas

G3/27 0092345 


\title{
New Generation of Plasma-Sprayed Mullite Coatings on Silicon Carbide
}

\author{
Kang N. Lee, ${ }^{, \dagger}$ Robert A. Miller, and Nathan S. Jacobson` \\ NASA-Lewis Research Center, Cleveland, Ohio 44135
}

\begin{abstract}
Mullite is promising as a protective coating for silicon-based ceramics in aggressive high-temperature environments. Conventionally plasma-sprayed mullite on $\mathrm{SiC}$ tends to crack and debond on thermal cycling. It is shown that this behavior is due to the presence of amorphous mullite in the conventionally sprayed mullite. Heating the $\mathrm{SiC}$ substrate during the plasma spraying eliminated the amorphous phase and produced coatings with dramatically improved properties. The new coating exhibits excellent adherence and crack resistance under thermal cycling between room temperature and $1000-1400^{\circ} \mathrm{C}$. Preliminary tests showed good resistance to $\mathrm{Na}_{2} \mathrm{CO}_{3}$-induced hot corrosion.
\end{abstract}

\section{Introduction}

Silicon-BAsed ceramics are promising candidate materials $\checkmark$ for high-temperature structural applications such as heat exchangers, gas turbine engines, and advanced internal combustion engines. They exhibit excellent oxidation resistance in dry air by forming a slow-growing silica $\left(\mathrm{SiO}_{2}\right)$ scale. ${ }^{1}$ However, these materials show poor environmental durability in molten salts or reducing atmospheres. ${ }^{1-4}$ Silica reacts with molten salts, forming a mixture of silica and liquid silicates. This results in an accelerated oxidation. In reducing atmospheres, they form gaseous silicon monoxide $(\mathrm{SiO})$.

One approach to improving the environmental durability of silicon-based ceramics is to apply refractory oxide coatings containing no silica or those with a lower silica activity. Mullite is most promising because of its environmental durability, chemical compatibility, and coefficient of thermal expansion (CTE) similar to that of SiC. Researchers at Oak Ridge National Laboratory, Oak Ridge, TN, and Solar Turbines, Inc., San Diego, CA, have done pioneering work on applying refractory oxide coatings on silicon carbide $(\mathrm{SiC}) .^{5.6}$ Techniques were developed to roughen the surface, which led to good coating adherence. Despite the roughened surface, as-plasma-sprayed coatings exhibited a strength distribution equivalent or superior to that of as-received $\mathrm{SiC} .^{7}$ This was attributed to the good mechanical bond between the coating and $\mathrm{SiC}$, presumably providing some load transfer to the coating from failureinitiating defects. In those studies, mullite was found to adhere and protect the best of those refractory oxide coatings tested. However, their mullite coatings tended to crack on thermal cycling.

Key issues related to the thermal shock resistance of coatings include CTE match, phase stability, and microstructure. The purpose of this paper is to critically evaluate plasma-sprayed mullite coatings with respect to the key issues. Development of a new mullite coating based on this evaluation is also discussed.

N. Claussen-contributing editor

Manuscript No. 193758. Received March 14, 1994; approved October 14, 1994 Member, American Ceramic Society.

Resident Research Associate from Cleveland State University. Cleveland. Ohio 44115.

${ }^{ \pm}$Average distance from the roughness profile to the mean line."

\section{Experimental Procedure}

Mullite was applied on SiC substrates (Hexoloy, Carborundum, Niagara Falls, NY) $(2.5 \mathrm{~cm} \times 0.6 \mathrm{~cm} \times 0.15 \mathrm{~cm})$ by atmospheric pressure plasma spraying. Plasma spraying is a high-velocity impact deposition process in which melting, quenching, and consolidation take place in a single step. ${ }^{8}$ In this process, mullite powder (fused or sintered mullite purchased from commercial vendors) is injected radially to the direction of a high-velocity and high-temperature plasma flow. Molten drops of mullite are produced, which are propelled rapidly toward a $\mathrm{SiC}$ substrate by the plasma flow and the high-velocity carrier gas. Upon impingement on the SiC substrate, the drops are quenched and solidified. A mullite coating is produced by the successive impingement of the drops (referred to as "splats") on the SiC substrate.

Thermal cycling tests in air and corrosion tests in molten $\mathrm{Na}_{2} \mathrm{CO}_{3}$ were conducted on mullite-coated $\mathrm{SiC}$ to evaluate the resistance to thermal shock and molten salt. Tested samples were mounted in epoxy, polished through $0.25-\mu \mathrm{m}$ diamond paste, coated with carbon, and examined by scanning electron microscopy (SEM). X-ray diffraction (XRD) was used to determine phases and lattice parameters; energy dispersive spectroscopy (EDS) was used for chemical analysis; differential thermal analysis (DTA) was used to investigate phase transformations; and dilatometry was used to measure CTEs.

\section{Results and Discussion}

\section{(1) Effects of Coating Parameters}

As a preliminary screening, several coating parameters were selected based on our previous experience with thermal barrier coatings (TBC) and their effects on coating properties were briefly investigated. Those selected were substrate roughness, powder particle size, plasma gun power, and carrier gas flow rate.

Figures 1(a) and (b) compare two substrates prepared by grit blasting and chemical etching $\left(\mathrm{Na}_{2} \mathrm{CO}_{3}, 880^{\circ} \mathrm{C}, 10 \mathrm{~h}\right)$, respectively. Chemical etching produced a more uniformly rough surface with higher roughness $\left(R_{\mathrm{a}}=6 \mu \mathrm{m}^{\ddagger}\right)$ than grit blasting $\left(R_{\mathrm{a}}=3.8 \mu \mathrm{m}\right)$. Coatings on chemically etched substrates were more adherent than those on grit-blasted substrates: as-sprayed coatings on grit-blasted substrates tended to debond partially or completely; meanwhile, those on chemically etched substrates remained bonded. Figures 2(a) and (b) compare two coatings sprayed with as-received $(-105 /+44 \mu \mathrm{m})$ and classified $(-62 /$

Table I. Coating Parameters Used in This Study

\begin{tabular}{ll} 
Surface preparation & Chemical etching \\
Particle size & $-62 /+20 \mu \mathrm{m}$ \\
Gun power & $40 \mathrm{~kW}$ \\
Plasma gas & $14.4 \mathrm{SLPM}^{\ddagger} \mathrm{Ar}, 9.6 \mathrm{SLPM} \mathrm{He}$ \\
Carrier gas & $6.0 \mathrm{SLPM} \mathrm{Ar}$ \\
Powder feed rate & $15 \mathrm{~g} / \mathrm{min}$ \\
Standoff & $15 \mathrm{~cm}$ \\
Traverse speed & $30 \mathrm{~cm} / \mathrm{s}$ \\
\hline
\end{tabular}

'Electroplasma Inc., California. ${ }^{\mathrm{t}}$ Standard liters per minute. 

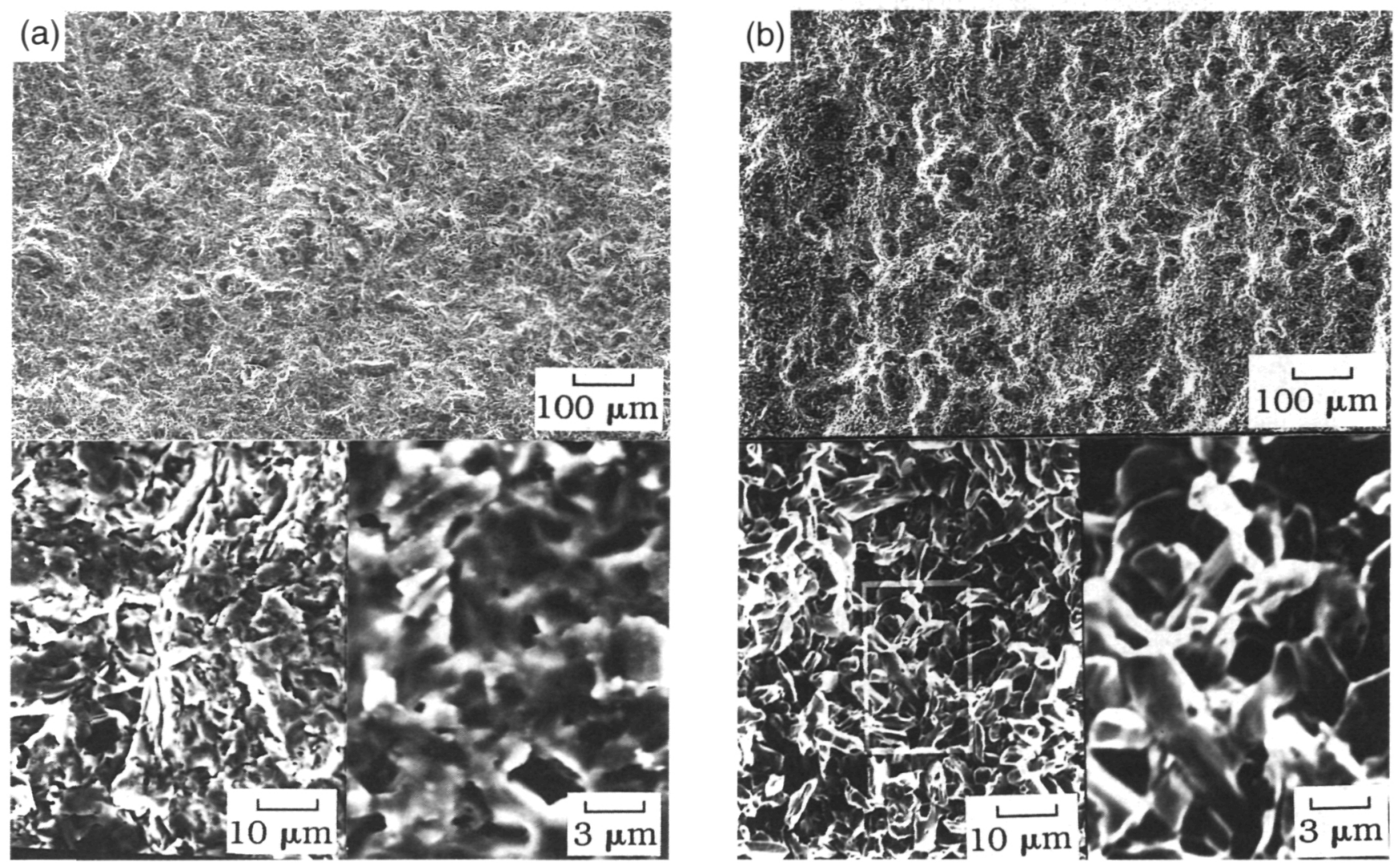

Fig. 1. Hexoloy $\mathrm{SiC}$ substrate after surface treatment: (a) grit blasted; (b) etched in molten $\mathrm{Na}_{2} \mathrm{CO}_{3}$ at $880^{\circ} \mathrm{C}$ for $10 \mathrm{~h}$.

$+20 \mu \mathrm{m}$ ) powder, respectively (chemically etched substrate, $35-\mathrm{kW}$ gun power). Classified powder produced a denser coating. Larger particles are more likely to melt incompletely, resulting in higher porosity. Increasing the gun power from 35 to $40 \mathrm{~kW}$ appeared to increase the density slightly. Coating density was also measured by varying the carrier gas flow rate between 2 and 6 standard liters per minute (SLPM) (chemically etched substrate, $40 \mathrm{~kW}$ power, classified powder). Mercury Archimedes density ${ }^{10}$ in conjunction with the theoretical density of stoichiometric mullite $\left(3.15 \mathrm{~g} / \mathrm{cm}^{3}\right)^{11}$ was used in the density measurement. Density ranged between $84 \%$ and $89 \%$ and did not appear to change significantly with the varying carrier gas flow rate. Based on these observations, the coating parameters in Table I were selected and used throughout this study unless stated otherwise.

\section{(2) Characterization of Plasma-Sprayed Mullite}

Figure 3 shows a mullite coating after two 24-h thermal cycles between room temperature (RT) and $1000^{\circ} \mathrm{C}$. Extensive debonding and cracking are noticed as reported in the previous studies. ${ }^{5,6}$ In this section, key fundamental properties of plasmasprayed mullite are critically evaluated to identify the cracking mechanism.

(A) Coefficient of Thermal Expansion: A free-standing coating cracked as severely as the coating on $\mathrm{SiC}$ when thermally cycled between RT and $1000^{\circ} \mathrm{C}$ (Fig. 4). This result coupled with the fact that the CTE of mullite $\left(5.3 \times 10^{-6} /{ }^{\circ} \mathrm{C}\right)^{12}$ is fairly close to that of $\mathrm{SiC}\left(4.7 \times 10^{-6} /{ }^{\circ} \mathrm{C}\right)^{12}$ indicates that CTE mismatch may not be a key factor for the cracking. To confirm the literature values, CTEs of $\mathrm{SiC}$ and plasma-sprayed mullite were measured (Fig. 5). The CTE of $\mathrm{SiC}$ was close to
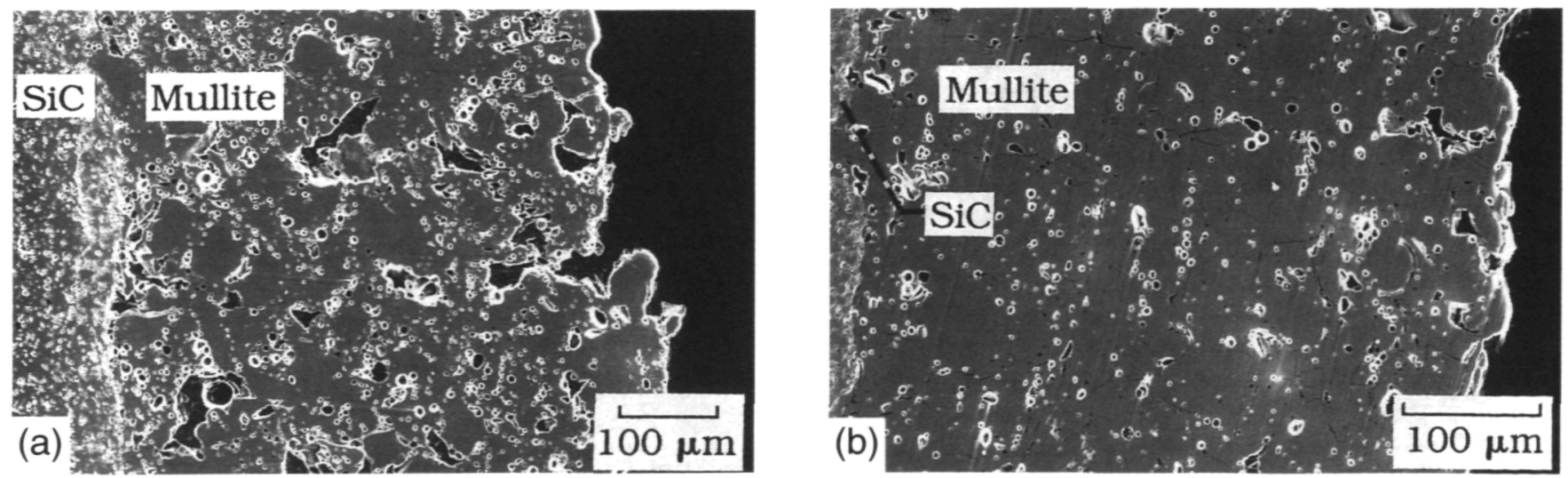

Fig. 2. Mullite coatings sprayed with powders of different particle size: (a) $-105 /+44 \mu \mathrm{m}$; (b) $-62 /+20 \mu \mathrm{m}$. 


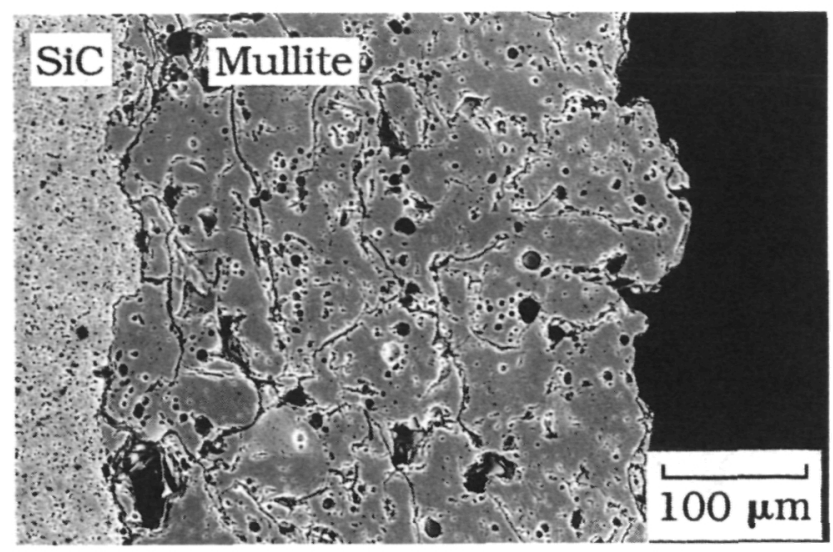

Fig. 3. Mullite coating after two 24-h thermal cycles between room temperature and $1000^{\circ} \mathrm{C}$.

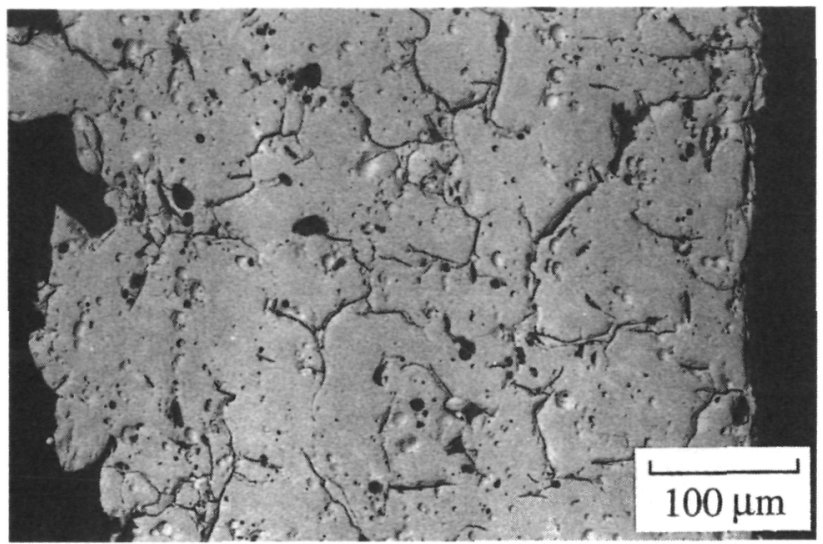

Fig. 4. Free-standing mullite coating after two 24-h thermal cycles between room temperature and $1000^{\circ} \mathrm{C}$.

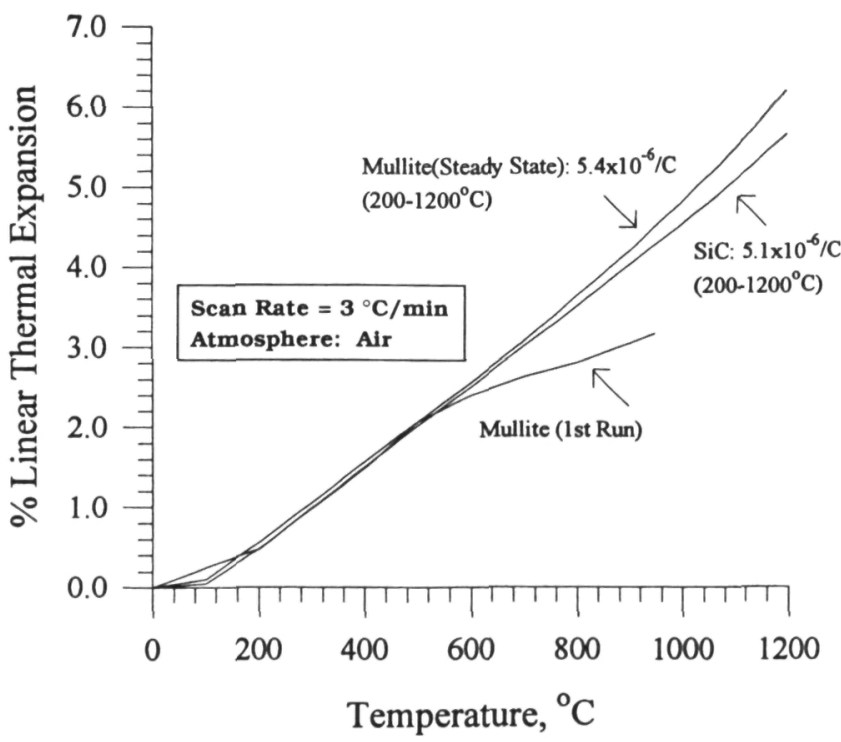

Fig. 5. Thermal expansion of plasma-sprayed mullite and Hexoloy silicon carbide.

that in the literature $\left(5.1 \times 10^{-6} /{ }^{\circ} \mathrm{C}\right)$. Mullite exhibited a steadystate CTE from the second measurement, which also agreed fairly well with that in the literature $\left(5.4 \times 10^{-6} /{ }^{\circ} \mathrm{C}\right)$. However, a considerable volumetric shrinkage was observed in the first measurement of mullite at temperatures between $600^{\circ}$ and

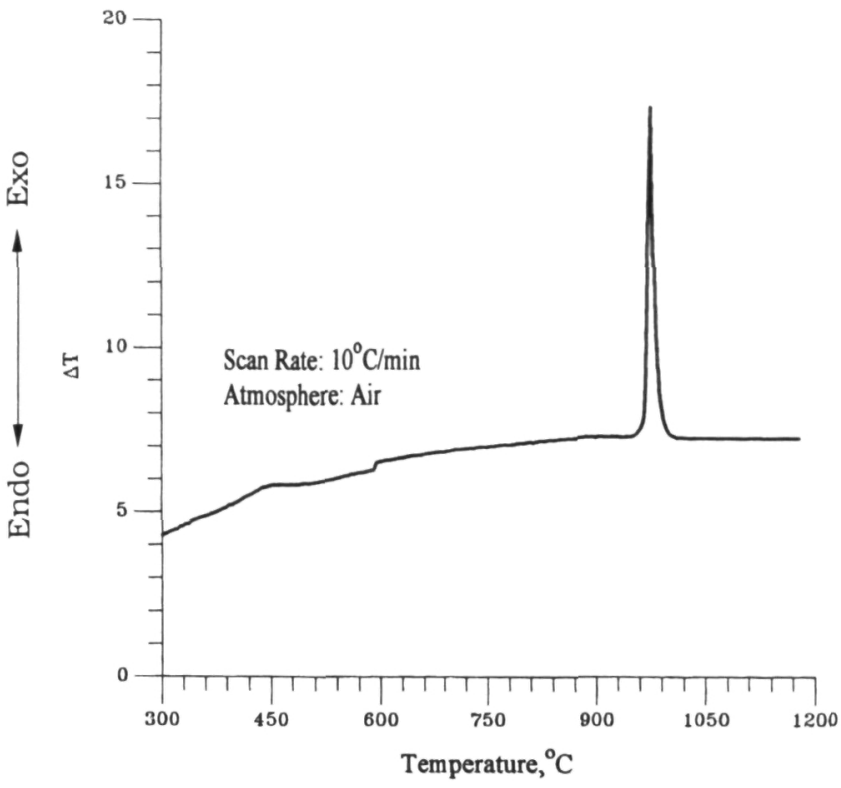

Fig. 6. Differential thermal analysis (DTA) of plasma-sprayed mullite.

$1000^{\circ} \mathrm{C}$. This initial shrinkage of mullite is likely to be very deterimental to its thermal shock resistance.

(B) Phase Transformations: Crystalline mullite does not sinter at temperatures below $1400{ }^{\circ} \mathrm{C},{ }^{13}$ suggesting that the initial shrinkage cannot be due to the sintering of crystalline mullite. However, amorphous mullite shrinks when it crystallizes at about $1000^{\circ} \mathrm{C} .{ }^{14}$ Amorphous mullite can form during plasma spraying when molten drops of mullite are rapidly quenched on a cold substrate. ${ }^{15} \mathrm{X}$-ray diffraction showed the presence of crystalline mullite. But it could not confirm the presence of amorphous mullite although a broad peak at low angles suggested that it may have been present. Differential thermal analysis showed an exothermic phase transformation at about $1000^{\circ} \mathrm{C}$ (Fig. 6). The crystallization temperature of amorphous mullite is also about $1000^{\circ} \mathrm{C}$, suggesting that the phase transformation observed by DTA may be crystallization. Therefore, both the initial volumetric shrinkage in the CTE measurement and the phase transformation in the DTA point toward the presence of amorphous mullite. This was further supported by an etching test. As-sprayed and thermally cycled mullite were etched in 10\% HF (Figs. 7(a) and (b), respectively). As-sprayed mullite exhibited extensive etching. This was ascribed to the dissolution of the amorphous phase due to its high chemical activity. The thermally cycled mullite did not show any etching because the amorphous mullite crystallized during the thermal cycling.

(C) Microstructure: When mullite is formed by a solidstate reaction between alumina and silica, a stable mullite with a nominal composition of $3 \mathrm{Al}_{2} \mathrm{O}_{3} \cdot 2 \mathrm{SiO}_{2}(71-74 \mathrm{wt} \%$ alumina) is formed. ${ }^{16,17}$ However, when mullite is grown from a melt, it forms metastable mullite with a nominal composition of $2 \mathrm{Al}_{2} \mathrm{O}_{3} \cdot \mathrm{SiO}_{2}$ (up to $78 \mathrm{wt} \%$ alumina) or $3 \mathrm{Al}_{2} \mathrm{O}_{3} \cdot \mathrm{SiO}_{2}$ (up to 83 $\mathrm{wt} \%$ alumina). ${ }^{16,17}$ Alumina content in mullite can be determined using the linear relationship between lattice parameter $a$ of mullite and its alumina concentration. ${ }^{18,19}$ Using this relationship in conjunction with the lattice parameter $a$ determined by XRD, the alumina content in plasma-sprayed mullite was $77-78 \mathrm{wt} \%$, in agreement with the reported value for a meltgrown mullite. ${ }^{17}$ Therefore, when mullite is grown from a melt having the stoichiometric $\left(3 \mathrm{Al}_{2} \mathrm{O}_{3} \cdot 2 \mathrm{SiO}_{2}\right)$ composition, which is the case in this study, a silica-rich glass phase precipitates to maintain the chemical balance (Figs. 8 and 9). In addition to the silica-rich phase, some alumina phase was detected in mullite by XRD. Figures 8 and 9 show microstructures and X-ray dot maps of mullite sprayed with two powder batches of low and 

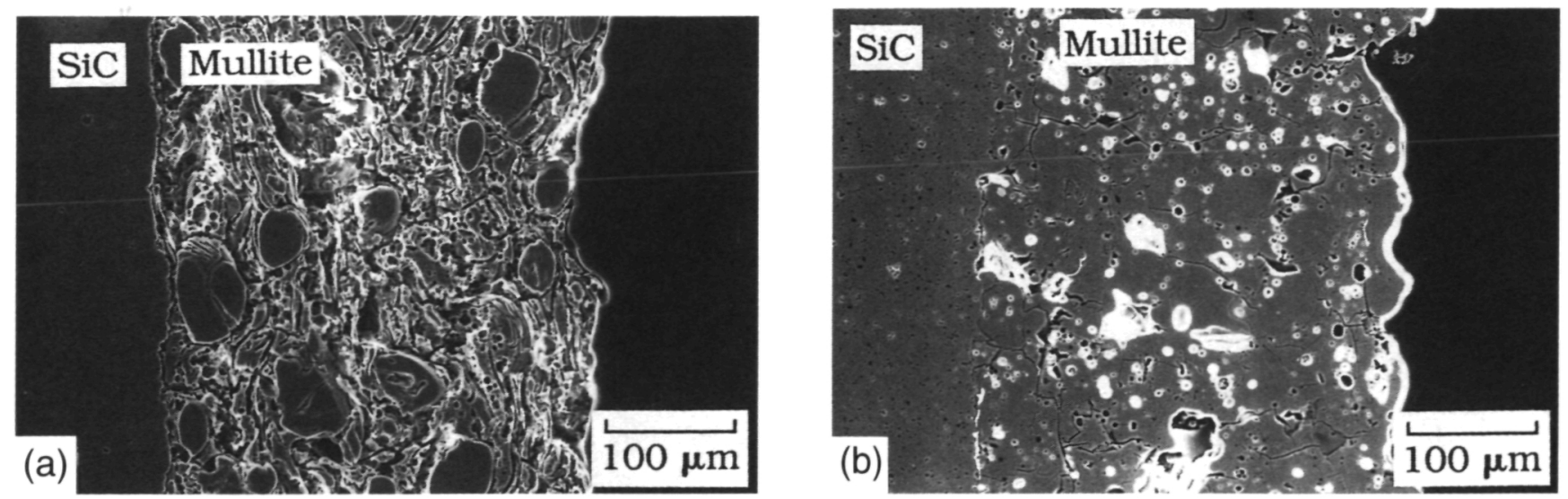

Fig. 7. Mullite coating etched in $10 \% \mathrm{HF}$ for $2 \mathrm{~min}$ : (a) as-sprayed; (b) after two 24 -h thermal cycles between room temperature and $1000^{\circ} \mathrm{C}$.
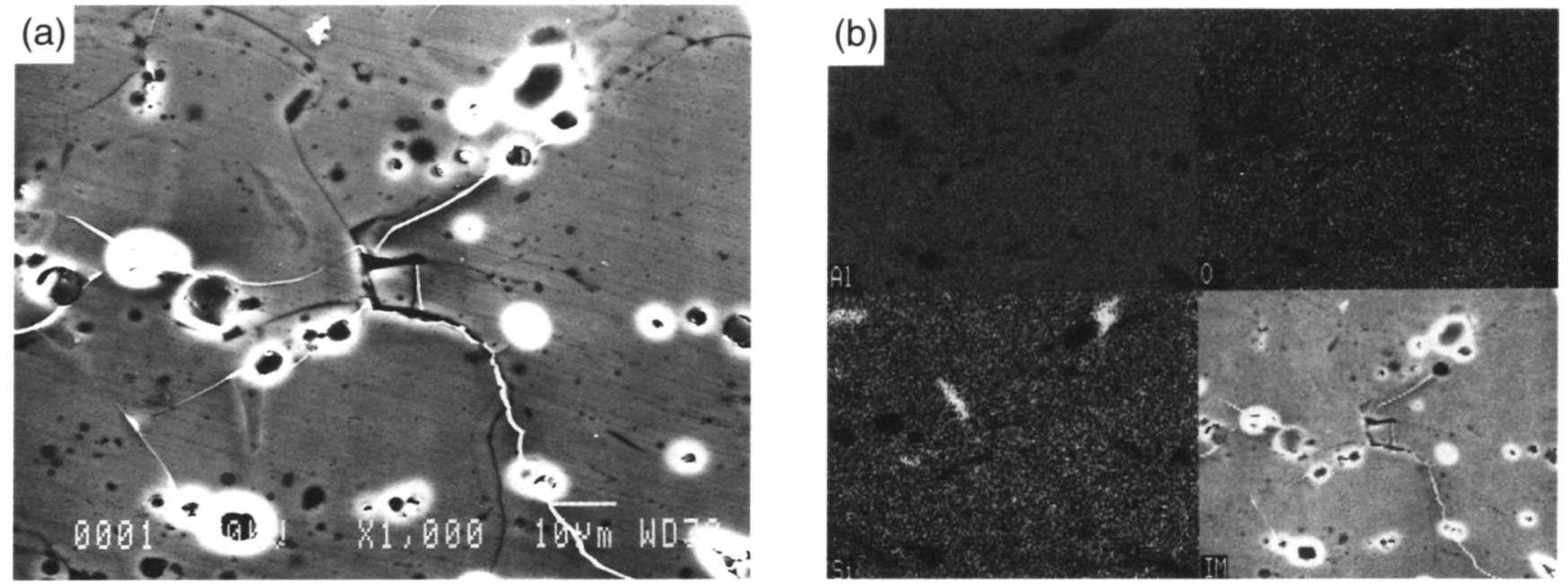

Fig. 8. Microstructure and X-ray dot maps of mullite coating sprayed with a mullite powder having low alumina impurity.
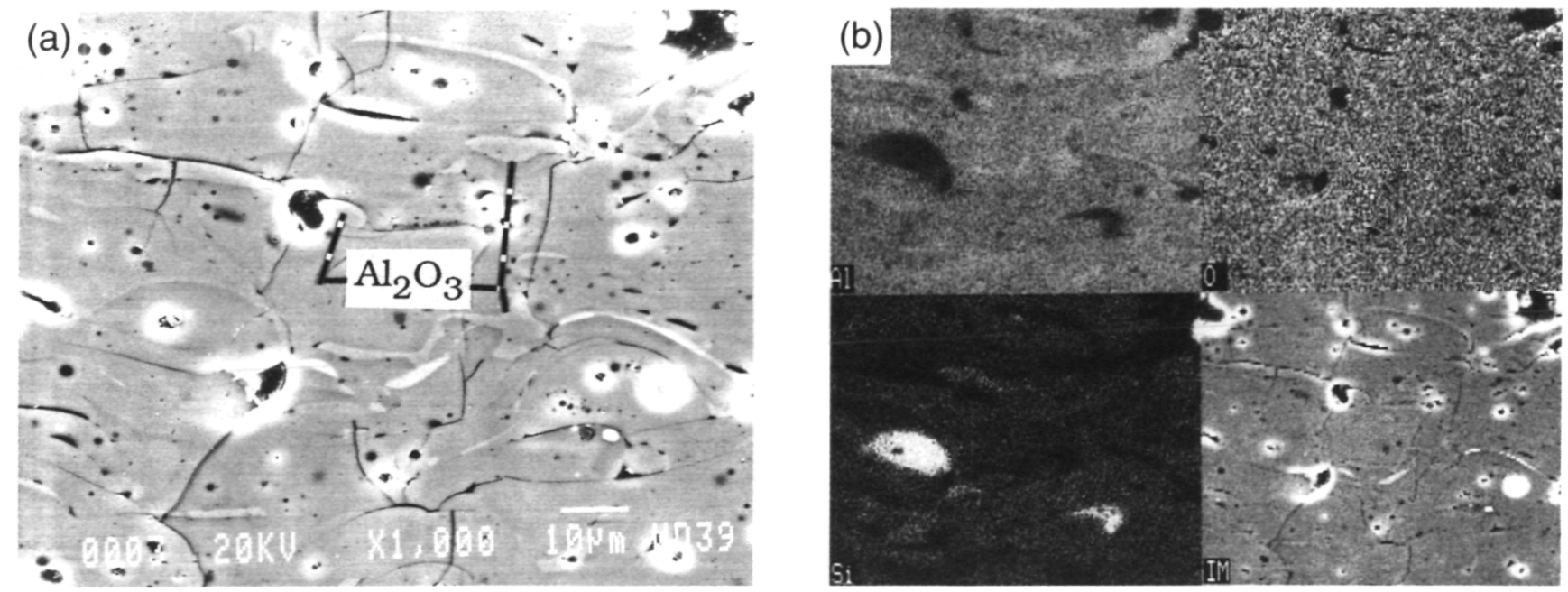

Fig. 9. Microstructure and X-ray dot maps of mullite coating sprayed with a mullite powder having high alumina impurity.

high alumina impurity, respectively. The powder with higher alumina impurity (Fig. 9) produced a coating with higher alumina precipitation. This indicates that the plasma-spraying process did not homogenize mullite. This is expected considering the brief time that the powder is in the plasma flame and the rapid cooling rate after striking the substrate (in excess of $\left.10^{6}{ }^{\circ} \mathrm{C} / \mathrm{s}^{20,21}\right)$. Note that the coating with higher alumina impurity (Fig. 9(a)) showed more cracking. The precipitation of alumina and silica can be detrimental to the thermal shock resistance of mullite because the differences in physical and mechanical properties between mullite and alumina or silica may cause a high residual stress.

Based on the above evaluation, crystallization of amorphous mullite with the associated volumetric shrinkage and the precipitation of alumina and silica-rich second phases are suggested as key mechanisms for the cracking of plasma-sprayed mullite 

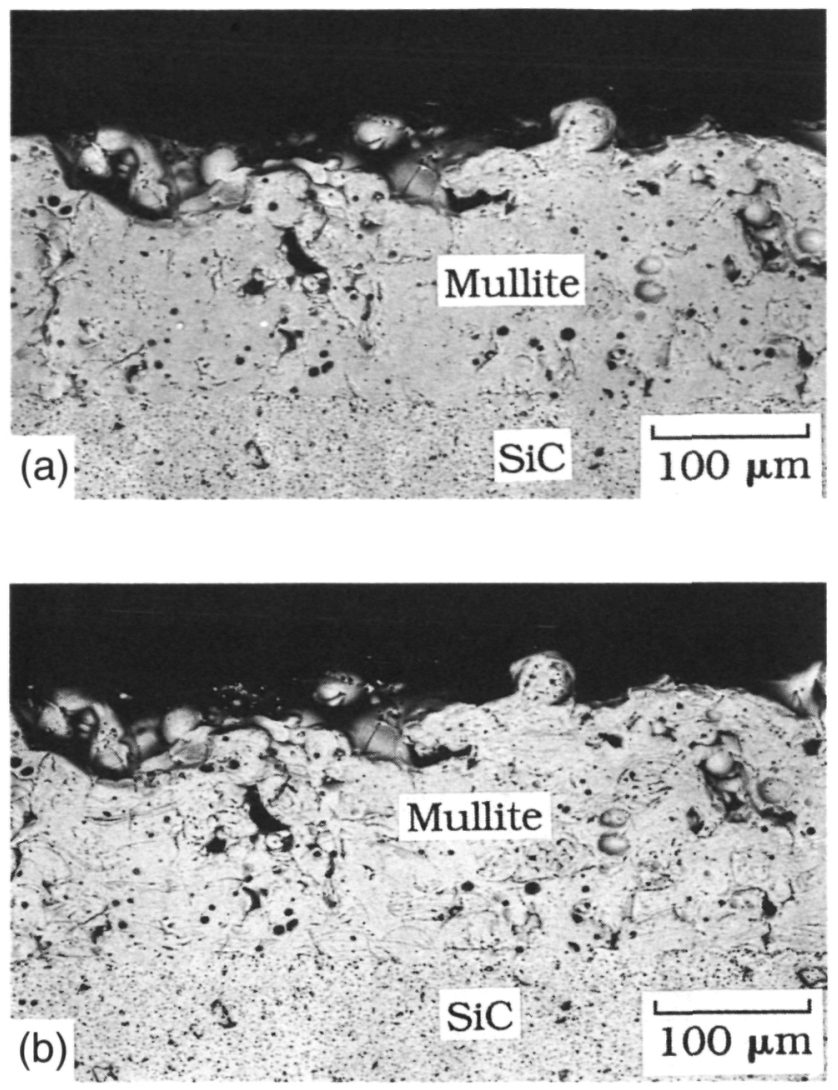

Fig. 10. Mullite coating sprayed at $T_{\text {substrate }}=1050^{\circ} \mathrm{C}$ : (a) as-sprayed; (b) etched in $10 \% \mathrm{HF}$ for $2 \mathrm{~min}$.

coatings. The precipitation of silica phase is an inherent property of melt-grown mullite and the precipitation of alumina phase is due to the impurity alumina in mullite powder. Therefore, the approach to improving the crack resistance of mullite coating in the next section will be limited to preventing the precipita-tion of amorphous mullite.

\section{(3) Development of a New Generation Mullite Coating}

Precipitation of amorphous mullite can be prevented by decreasing the cooling rate. One approach to decreasing the cooling rate is to heat the substrate during the spraying. A first attempt was made to heat the substrate with a plasma torch. However, it was not possible to attain a uniform and stable substrate temperature with the plasma torch heating. A severe cracking in the substrate was observed when mullite was sprayed on a plasma-torch-heated SiC. Amorphous mullite was still observed, indicating that substrate was heated below the crystallization temperature (as will be shown later, the substrate must be heated above the crystallization temperature to obtain fully-crystalline mullite). The reason for the substrate-cracking when underheated is not understood at this point.

A uniform substrate temperature could be attained using a modified molydisilicide box furnace. Figures 10(a) and (b) show a mullite coating applied at $T_{\text {substrate }}=1050^{\circ} \mathrm{C}$, as-sprayed and etched, respectively. It showed negligible dissolution in $\mathrm{HF}$, indicating that heating the substrate at $1050^{\circ} \mathrm{C}$ fully crystallized mullite. ${ }^{22}$ Figure 11 shows the same mullite coating after two 24-h cycles between RT and $1000^{\circ} \mathrm{C}$. Note the dramatic improvement in crack resistance compared to the conventional mullite in Fig. 3. This indicates that the crystallization of amorphous mullite is the key mechanism for the cracking and debonding of the conventional mullite coatings. X-ray diffraction indicated that mullite coatings applied on heated substrates contain smaller amounts of alumina compared to conventional

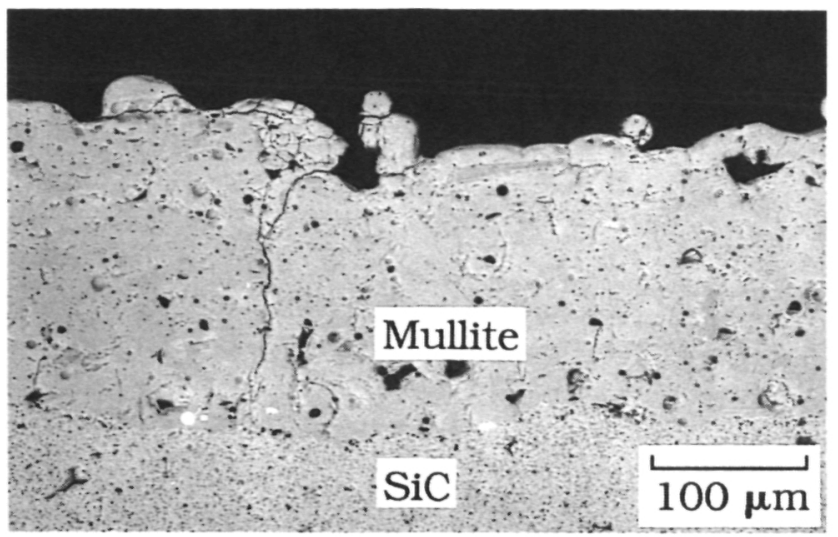

Fig. 11. Fully-crystalline mullite coating after two 24-h thermal cycles between room temperature and $1000^{\circ} \mathrm{C}$.

mullite coatings. SEM and EDS analyses also supported the XRD observations.

\section{(4) Environmental Durability}

Some preliminary environmental durability tests were conducted for the new mullite coatings. Figure 12 shows a mullite coating subjected to ten 20 -h cycles between RT and $1400^{\circ} \mathrm{C}$. Most of the interface was still intact with no substantial cracking (Fig. 12(a)), except for some debonding and cracking at the edge of the sample (Fig. 12(b)). The new mullite coating was also tested for corrosion resistance in molten $\mathrm{Na}_{2} \mathrm{CO}_{3} \cdot \mathrm{Na}_{2} \mathrm{CO}_{3}$ was chosen as a model salt because it is strongly basic and thus highly corrosive to silicon-based ceramics. ${ }^{2}$ Mullite-coated SiC was coated with $\mathrm{Na}_{2} \mathrm{CO}_{3}$ by spraying $3 \mathrm{mg} / \mathrm{cm}^{2}$ of $\mathrm{Na}_{2} \mathrm{CO}_{3}$ and subsequently exposed to $1000^{\circ} \mathrm{C}$ for $24 \mathrm{~h}$. Figure 13 shows the cross-section and X-ray dot maps of the coated SiC after exposure. Molten salt attack was limited to the surface of the coating where the formation of solid sodium aluminum silicates was confirmed by XRD. This is a dramatic improvement compared to the hot corrosion of uncoated $\mathrm{SiC}$ in $\mathrm{Na}_{2} \mathrm{CO}_{3} .{ }^{2} \mathrm{How}-$ ever, recent results indicate that some $\mathrm{Na}$ may penetrate to the coating/SiC interface through microcracks. ${ }^{23}$ Further research is needed to address this issue.

\section{Conclusion}

Critical evaluation of plasma-sprayed mullite identified the crystallization of amorphous mullite as the key mechanism for the cracking of conventional mullite coatings under thermal cycling. Amorphous mullite is precipitated during the rapid solidification of molten mullite and subsequently crystallizes when exposed to $T>1000^{\circ} \mathrm{C}$. Volumetric concentration due to the crystallization causes fragmentation of the structure and cracking.

A new plasma-spraying process has been developed which produces fully-crystalline mullite. In the new process, the precipitation of amorphous mullite is prevented by heating the substrate above the crystallization temperature. Fullycrystalline mullite coating exhibited a dramatically improved crack resistance compared to conventional mullite coatings under thermal cycling. The new mullite coating also provided $\mathrm{SiC}$ substrates an excellent protection in molten $\mathrm{Na}_{2} \mathrm{CO}_{3}$. More detailed characterization and process optimization are necessary to further tailor the coating properties.

Acknowledgment: We would like to acknowledge the exceptional work of George Leissler of Sverdrup Technologies for preparing plasma-sprayed mullite coatings. 

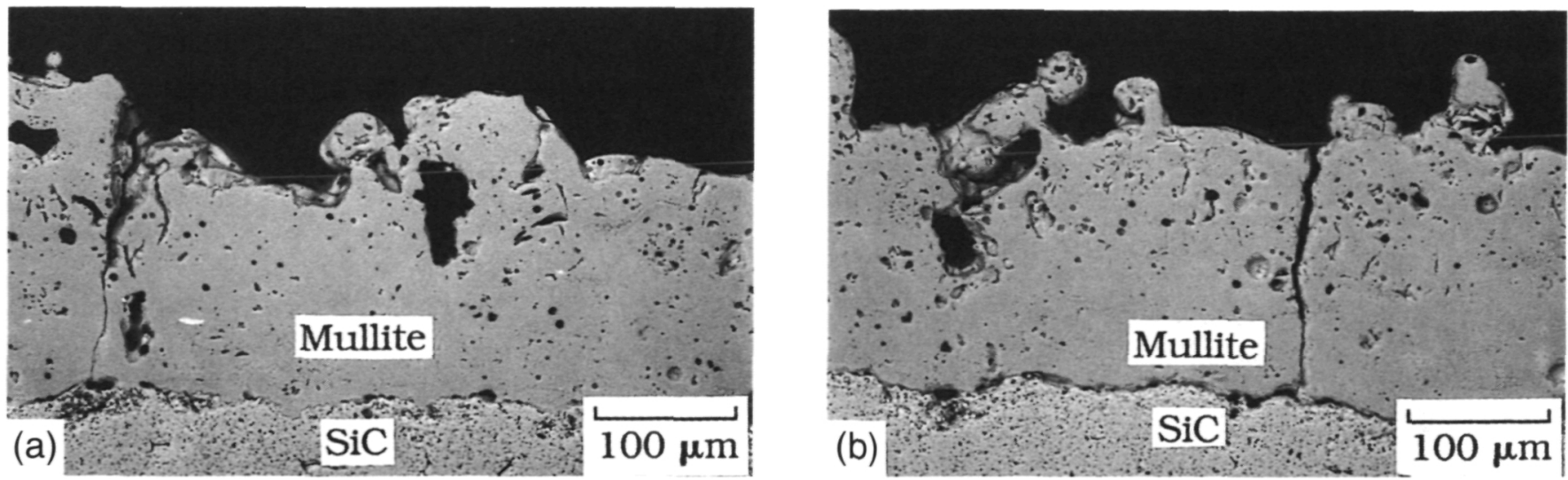

Fig. 12. Fully-crystalline mullite coating after ten 20 -h thermal cycles between room temperature and $1400^{\circ} \mathrm{C}$ : (a) bonded area; (b) debonded area.
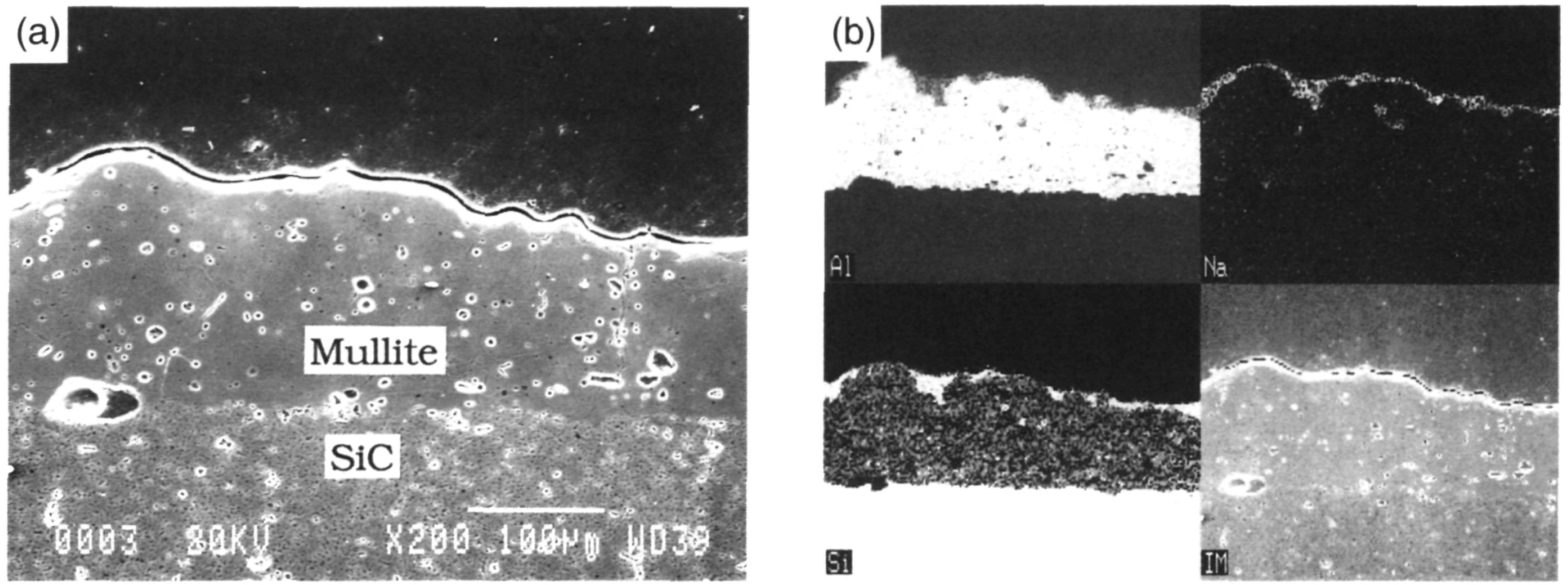

Fig. 13. Fully-crystalline mullite coating after 24 -h isothermal exposure at $1000^{\circ} \mathrm{C}$ in the presence of $\mathrm{Na}_{2} \mathrm{CO}_{3}$ deposit.

\section{References}

${ }^{1}$ N. S. Jacobson, "Corrosion of Silicon-Based Ceramics in Combustion Environments," J. Am. Ceram. Soc., 76 [1] 3-28 (1993).

${ }^{2}$ N. S. Jacobson, J. L. Smialek, and D. S. Fox, "Molten Salt Corrosion of SiC and $\mathrm{Si}_{3} \mathrm{~N}_{4}$ "; pp. 99-135 in Handbook of Ceramics and Composites, Vol. 1. Edited by N. P. Cheremisinoff. Marcel Dekker, New York, 1990.

A. K. Misra, "Thermodynamic Analysis of Chemical Stability of Ceramic Materials in Hydrogen-Containing Atmospheres at High Temperatures," NASA Contractor Report 4271, NASA-Lewis Research Center, Cleveland, OH, 1990.

${ }^{4}$ D. P. Butt, R. E. Tressler, and K. E. Spear, "Corrosion of SiC Materials in $\mathrm{N}_{2}-\mathrm{H}_{2}-\mathrm{CO}$ Gaseous Environments: I. Thermodynamics and Kinetics of Reactions," J.Am.Ceram. Soc., 75 [12] 3257-67 (1992).

${ }^{5} \mathrm{~J}$. I. Federer, "Alumina Base Coatings for Protection of SiC Ceramics," J. Mater. Eng., 12 [2] 141-49(1990).

${ }^{6}$ J. R. Price, M. van Roode, and C. Stala, "Ceramic Oxide-Coated Silicon Carbide for High-Temperature Corrosive Environments," Key Eng. Mater. 72-74, 71-84 (1992)

'D. P. Butt, J. J. Mecholsky, Jr., M. van Roode, and J. R. Price, "Effects of Plasma-Sprayed Ceramic Coatings on the Strength Distribution of Silicon Carbide Materials," J.Am. Ceram. Soc. 73 [9] 2690-96 (1990).

${ }^{8}$ C. C. Berndt, W. Brindley, A. N. Goland, H. Herman, D. L. Houck, K. Jones, R. A. Miller, R. Neiser, W. Riggs, S. Sampath, M. Smith, and P. Spanne, "Current Problems in Plasma Spray Processing," J. Therm. Spray Technol., 1 [4] 341-56 (1992)

${ }^{9}$ American National Standards Institute/American Society of Mechanical Engineers, ANSI/ASME B46-1-1985, Surface Texture, 13-15 (1985).

${ }^{10}$ R. A. Miller, G. W. Leissler, and J. M. Jobe, "Characterization and Durability Testing of Plasma-Sprayed Zirconia-Yttria Thermal Barrier Coatings," NASA Technical Paper 3295. NASA-Lewis Research Center. Cleveland, OH, 1993.
I"R. C. Weast and M. J. Astle (Eds.), CRC Handbook of Chemistry and Physics. CRC Press, Boca Raton, FL, 1980.

${ }^{{ }^{i 2}}$ Y. S. Touloukian, R. K. Kirby, R. E. Taylor, and T. Y. R. Lee, Thermophysical Properties of Matter, Vol. 13. IFI/Plenum, New York, 1977.

${ }^{13} \mathrm{P}$. Boch and T. Chartier, "High-Purity Mullite Ceramics By Reaction-Sintering," Ceram. Trans., 6, 353-74 (1990).

${ }^{14} \mathrm{~S}$. Somiya and Y. Hirata, "Mullite Powder Technology and Applications in Japan," Am. Ceram. Soc. Bull., 70 [10] 1624-32 (1991).

${ }^{15} \mathrm{~T}$. Takeshi and R. Roy, "Rapid Crystallization of $\mathrm{SiO}_{2}-\mathrm{Al}_{2} \mathrm{O}_{3}$ Glasses," J. Am. Ceram. Soc., 56 [12] 639-44 (1973).

${ }^{16}$ I. A. Aksay and J. A. Pask, "Stable and Metastable Equilibria in the System $\mathrm{SiO}_{2}-\mathrm{Al}_{2} \mathrm{O}_{3}$, J. Am. Ceram. Soc., 58 [11-12] 507-12 (1975).

${ }^{17}$ W. M. Kriven and J. A. Pask, "Solid Solution Range and Microstructure of Melt-Grown Mullite," J. Am. Ceram. Soc., 66 [9] 649-54 (1983).

${ }^{18}$ F. J. Klug, S. Prochazka, and R. H. Doremus, "Alumina-Silica Phase Diagram in the Mullite Region," J. Am. Ceram. Soc., 70 [10] 750-59 (1987),

${ }^{19}$ W. E. Cameron, "Composition and Cell Dimensions of Mullite," Am. Ceram. Soc. Bull., 56 [11] 1003-11 (1977).

${ }^{20} \mathrm{~S}$. Safai and H. Herman, "Microstructural Investigation of Plasma-Sprayed Aluminum Coatings," Thin Solid Films, 45, 295-307 (1977).

${ }^{2}$ S. Sampath, "Rapid Solidification during Plasma Spraying"; Ph.D. Thesis. State University of New York, Stony Brook, NY, August, 1989.

${ }^{22}$ K. N. Lee, R. A. Miller, and N. S. Jacobson, "Plasma-Sprayed Mullite Coatings on Silicon-Based Ceramics," U.S. Pat. Application Serial No. 08/031.444

${ }^{23} \mathrm{~K}$. N. Lee, N. S. Jacobson, and R. A. Miller, "Refractory Oxide Coatings on SiC Ceramics," MRS Bull., 14 [10] 35-38 (1994). 